\title{
PURIFICATION AND CHARACTERIZATION OF A SERRATIA MARCESCENS NUCLEASE PRODUCED BY ESCHERICHIA COLI
}

\author{
by \\ KIRSTEN BIEDERMANN"), PIA KNAK JEPSEN"), ERIK RIISE ${ }^{2)}$ and IB SVENDSEN \\ Department of Chemistry, Carlsberg Laboratory, \\ Gamle Carlsberg Vej 10, DK-2500 Copenhagen Valby \\ 1) Department of Biotechnology, The Technical University of Denmark, \\ DK-2800 Lyngby, Denmark \\ 2) Department of Microbiology, The Royal Danish School of Pharmacy, \\ Universitetsparken 2, DK-2100 Copenhagen Ø, Denmark
}

Keywords: E. coli, secretion, nuclease, purification, primary structure

The primary structure and physical chemical properties were determined of a nuclease expressed and secreted by Escherichia coli. The plasmid p403-SD2 carried a DNA sequence isolated from Serratia marcescens encoding the enzyme. During cultivation of the E. coli cells, $85 \%$ of the enzyme was released to the growth medium. The enzyme was purified and exhibited a single band with a molecular weight about 30,600 daltons on SDS-PAGE similar to nuclease isolated from $\mathrm{S}$. marcescens. The amino acid composition and the amino acid sequence determined directly confirmed the primary structure of 245 amino acids predicted from the DNA sequence, and, in addition, the two disulfide bridges were assigned. Several physical chemical properties were examined. The ability of the enzyme to cross the outer membrane is proposed to depend upon the formation of the proper structures during the folding process.

\section{INTRODUCTION}

Excretion vectors giving rise to export of recombinant products from host cells have gained interest in order to overcome complications seen by overproduction of intracellular products. The transport across the inner membrane of $E$. coli can be achieved with vectors constructed from DNA sequences encoding the desired product in frame with an $\mathrm{N}$-terminal signal sequence of $\mathrm{E}$. coli origin (24). The products are secreted to the periplasm but do not usually pass the outer membrane. Recently, a few gene products have been produced that are also excreted by E. coli (15, 19). The genes involved in the excretion originated from Staphylococcus aureus and alkalophilic Bacillus. However, E. coli is also able to release several of the extracellular enzymes of Serratia marcescens $(1,11,14,28)$. It is not clear why the enzymes are released. In case of nuclease a weak induction of the SOS-system was observed which normally arises as a result of DNA damage. However, it was suggested that some of the information required for secretion is within the protein itself. We have studied the secretion of Serratia marcescens nuclease from E. coli $(8,14)$, We have found that the enzyme is secreted to the periplasm and is released to the growth medium. However, the amount of extracellular enzyme is affected by 
the host strain used and the growth conditions of the cells. In order to find any relation between extracellular excretion and structure or properties of the enzyme we isolated and characterized the extracellular nuclease from $\mathrm{E}$. coli cell cultures.

Extracellular nuclease from $\mathrm{S}$. marcescens has previously been studied $(6,10,21,29)$. The enzyme degrades single and double stranded DNA and RNA without any base specificity (22). but apparently none of the isolated enzymes have the same physical and chemical properties. Therefore, results of the properties of the purified enzyme were compared with reported studies of other $S$. marcescens nucleases.

\section{MATERIALS AND METHODS}

\subsection{Bacterial strain and plasmid}

Plasmid p403-SD2 is constructed from pGV403 (Amersham Code no. RPN 1252) by inserting a 1300 base pairs DNA fragment isolated from Serratia marcescens. The insert consists of a region with an open reading frame of 735 base pairs encoding the enzyme nuclease $(1,20)$. Bacterial strain E. coli MT102 (hsd R) was obtained from M.T. HANSEN, Novo Industri $\mathrm{A} / \mathrm{S}$. This strain is a derivative of $\mathrm{MC} 1000$ (ara D 139 (ara, leu ) $\Delta 7697$, lac $\Delta 74$, gal $\mathrm{K}$, gal U, strp L, strp ${ }^{-}$. Transformants of MT102 with p403-SD2 were resistant to chloramphenicol. S. marcescens strain W225 (wild type) (27) was obtained from Dr. U. WINKLER.

\subsection{Cell growth}

E. coli was cultivated in 15 litre fermentors. The LB broth ( $1 \%$ Bacto tryptone (Difco), $0.5 \%$ yeast extracts (Difco) and $1 \% \mathrm{NaCl}$ ) was adjusted to 8.4 with $2 \mathrm{~N} \mathrm{NaOH}$. After autoclaving the LB broth glucose was added to a concentration of $0.2 \%(w / v)$. An overnight culture grown at $28{ }^{\circ} \mathrm{C}$ in the presence of chloramphenicol $(20 \mu \mathrm{g} / \mathrm{ml})$, was used as inoculum. The cells were grown at $35{ }^{\circ} \mathrm{C}$ with aeration $(1 \mathrm{vol} / \mathrm{vol} / \mathrm{min})$ and stirring $(500 \mathrm{rpm})$. S. marcescens was grown in $\mathrm{LB}$ broth having $\mathrm{pH}=7.8$, containing $0.2 \%$ glucose. The cells were grown at $30{ }^{\circ} \mathrm{C}$ with aeration ( $1 \mathrm{vol} / \mathrm{vol} / \mathrm{min}$ ) and stirring $(500 \mathrm{rpm})$.

\subsection{Analytical releasing methods}

Osmotic shock treatment (23) was performed on cells from $2 \mathrm{ml}$ of cell culture. The amount of nuclease released was the sum of activities released into the sucrose solution, the shock fluid and the spheroplast wash. Sonication of whole cells corresponding to $4 \mathrm{ml}$ cell culture suspended in $4 \mathrm{ml} 10 \mathrm{~mm}$ Tris- $\mathrm{HCl} \mathrm{pH} 8.3$ was performed with a Branson 250 sonicator over a period of 5 min at $25 \mathrm{Watt}$, while the cells were cooled with ice.

\subsection{Isolation and purification}

Cells from approx. 13 litres of culture broth were separated from the growth medium by tangential flow filtration (the Pellican casette systems from Millipore) using microporous membranes of $0.45 \mu \mathrm{m}$ pore size (Millipore type HVLP0001).

The clarified medium was concentrated and diafiltrated in the same filtration unit equipped with an ultrafiltration membrane with a cut off at a molecular weight of 10,000 (Millipore type PTGC0005). The concentrated medium was diafiltrated with $10 \mathrm{~mm}$ Tris- $\mathrm{HCl} \mathrm{pH} 8.3$ and a final volume of approx. 1 litre was achieved. The nuclease remaining in the periplasm was released by osmotic shock treatment of the cells (3).

Ammonium sulfate was added to a conc. of $80 \%$ (saturation) and the precipitate formed was collected by centrifugation for $30 \mathrm{~min}$ at $14,000 \times \mathrm{g}$. The pellets were dissolved in $10 \mathrm{~mm}$ Tris- $\mathrm{HCl} \mathrm{pH} 8.3$ and dialyzed against the same buffer overnight. The dialysate was applied to a DE-52 (Whatman) column $(5 \mathrm{~cm} \times 5 \mathrm{~cm})$ previously equilibrated with the same buffer. The adsorbed protein was eluted with the buffer containing a linear gradient of $\mathrm{NaCl}$ from 0 to $0.3 \mathrm{M}$. The nuclease active fractions were pooled, adjusted to $\mathrm{pH} 5.6$ with acetic acid and applied to a CM-Sepharose CL-6B (Pharmacia) column $(2.6 \mathrm{~cm} \times 10 \mathrm{~cm})$ previously equilibrated with $20 \mathrm{~mm}$ sodium-acetate $\mathrm{pH}$ 5.6. The adsorbed nuclease was eluted with the buffer containing a linear gradient of $\mathrm{NaCl}$ from 0 to $0.5 \mathrm{M}$. The active fractions were pooled, dialyzed against distilled water and lyophilized. 


\subsection{Amino acid analysis}

Duplicate samples of the nuclease were hydrolized at $110^{\circ} \mathrm{C}$ for 24,48 , and $72 \mathrm{~h}$ in $5.7 \mathrm{M}$ $\mathrm{HCl}$ in evacuated and sealed tubes. The values for serine and threonine were obtained by extrapolation to 0-time and the values obtained at $72 \mathrm{~h}$ were used for valine and isoleucine. Halfcystine was determined as cysteic acid after oxidation with $\mathrm{H}_{2} \mathrm{O}_{2}$ (13). The amino acid analysis was made on a Durrum D500 amino acid analyzer. Tryptophan was determined spectrophotometrically (7). Free sulfhydryl groups were determined with Ellman's reagent (25).

\subsection{Amino acid sequencing}

Amino acid sequence determination was conducted on an Applied Biosystem gas-phase amino acid sequencer model $470 \mathrm{~A}$ according to the specifications given by the manufacturer. Detection of PTH-amino acids was made on an on-line HPLC, model 120A, from Applied Biosystem. Cleavage of the nuclease with $\mathrm{CNBr}$ was performed overnight in $70 \%$ formic acid at room temperature in the dark. A 100 fold molar excess of $\mathrm{CNBr}$ was used. The generated fragments were separated on a Biogel P60 (0.9 $\mathrm{cm} \times 90 \mathrm{~cm}$ ) column equilibrated and eluted with $30 \%$ acetic acid. Relevant peaks were pooled and lyophilized. The nuclease was cleaved with activated clostripain $(1: 100)$ in $20 \mathrm{mM} \mathrm{NH}{ }_{4} \mathrm{HCO}_{3}$ overnight at $30^{\circ} \mathrm{C}$. The resulting peptides were separated by HPLC (Bondapak $\mathrm{C}_{18}$, Widepore) using a 5 to $40 \%$ gradient in acetonitrile over $45 \mathrm{~min}$. The peptides were detected at $220 \mathrm{~nm}$ and relevant peaks were freeze dried.

\subsection{Other general procedures}

Cell density was measured directly or after dilution with $0.9 \% \mathrm{NaCl}$ as optical density at 450 $\mathrm{nm}$. Nuclease activity was estimated as the ability to degrade DNA (21). The substrate was calf thymus DNA (lyophilized research grade from Serva, no. 18560, Heidelberg). One unit of

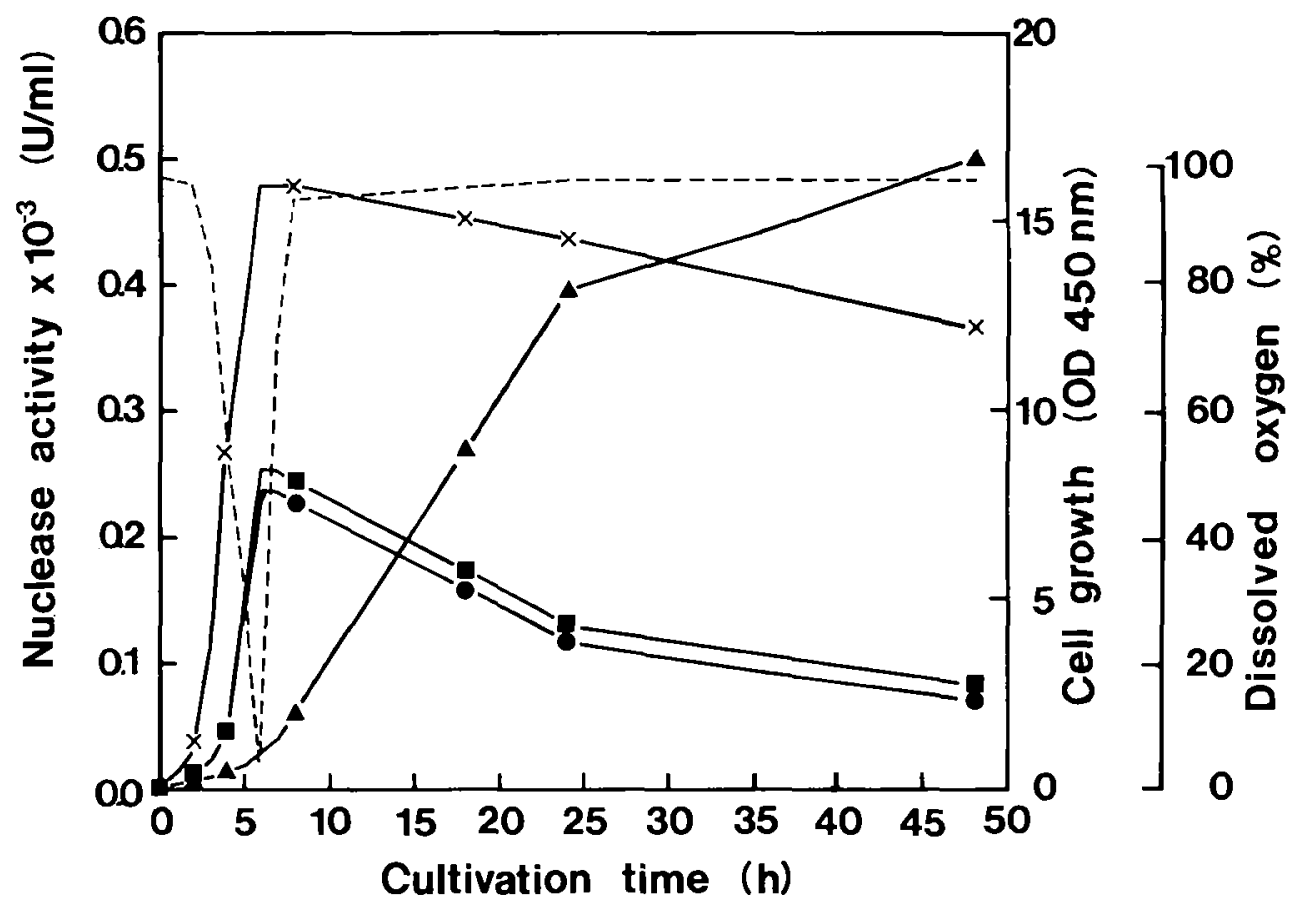

Figure 1. Production of nuclease by E. coli MT102(p403-SD2); $\times$, cell density (absorbance at $450 \mathrm{~nm}$ ); $\boldsymbol{\Delta}$, extracellular nuclease activity $(\mathrm{U} / \mathrm{ml}) ; \boldsymbol{\square}$, cell bound nuclease activity $(\mathrm{U} / \mathrm{ml})$ in clarified extracts of sonicated whole cells; $\odot$, periplasmic nuclease activity $(\mathrm{U} / \mathrm{ml})$ released by osmotic shock; ---, dissolved oxygen $(\%)$. 
Table I. Purification of extracellular S. marcescens nuclease from E. coli

\begin{tabular}{llllll}
\hline Step $^{\mathrm{a}}$ & $\begin{array}{l}\text { Volume } \\
(\mathrm{ml})\end{array}$ & $\begin{array}{l}\text { Total } \\
\text { activity } \\
(\mathrm{U})\end{array}$ & $\begin{array}{l}\text { Total } \\
\text { protein } \\
(\mathrm{mg})\end{array}$ & $\begin{array}{l}\text { Specific } \\
\text { activity } \\
(\mathrm{U} / \mathrm{mg})\end{array}$ & $\begin{array}{l}\text { Yield } \\
\%\end{array}$ \\
\hline Culture fluid & 13,000 & $3,900,000$ & 1,900 & 2,100 & 100 \\
and cell wash & & & & 2,200 & 97 \\
Ultrafiltration & 1,200 & $3,800,000$ & 1,700 & 4,300 & 90 \\
Ammonium sulfate & 80 & $3,500,000$ & 810 & 29,000 & 85 \\
DE-52 & 130 & $3,300,000$ & 114 & 40,000 & 62 \\
CM-Sepharose and & 28 & $2,400,000$ & 60 & & \\
lyophilization & & & & & \\
\hline
\end{tabular}

a Purification procedure and unit description are as described under "Materials and Methods".

nuclease activity is defined as the amount of enzyme causing an increase of 1.0 in absorbancy at $260 \mathrm{~nm}$ after $1 \mathrm{~min}$ at $37^{\circ} \mathrm{C}$. DNase test agar (Difco) was used for qualitative nuclease activity determination. The activity was visualized as clearing zones on the plates after non-degraded DNA had been precipitated with $1 \mathrm{~N} \mathrm{HCl}$. Protein determination during the purification was estimated as described by BRADFORD (4). Polyacrylamide gel electrophoresis was performed in the presence of SDS as described by LAEMMLI (18) using 10\% acrylamide and $0.1 \%$ SDS. The proteins were stained with Coomassie Brillant Blue G-250. Electroblotting of the gels was performed as described by KYHSE-ANDERSEN (16). Isoelectric focusing was performed on LKB Ampholine PAG-plates pH 3.5 - 9.5. Molecular weight was determined by HPLC gelfiltration (LKB TSK G3000 SW) in $0.02 \mathrm{M}$ sodium phosphate buffer $\mathrm{pH} 6.8$ containing 0.1 $\mathrm{M} \mathrm{Na} \mathrm{SO}_{4}$.

\section{RESULTS}

\subsection{Purification of nuclease}

The results from the cultivation of the E. coli cells are shown on Figure 1. It is seen that there is a burst in periplasmic nuclease formation at late exponential growth phase. At stationary growth phase the enzyme is released to the growth medium and an extracellular activity of $500 \mathrm{U} / \mathrm{ml}$ is reached. It is also seen that all enzyme activity is found to be present both extracellularly and in the periplasm. We did not observe any plasmid loss during the cultivation. S. marcescens strain W225 was cultivated in order to isolate the nuclease and verify the similarity between the cloned and the "wild type". However, this strain only released nucle-

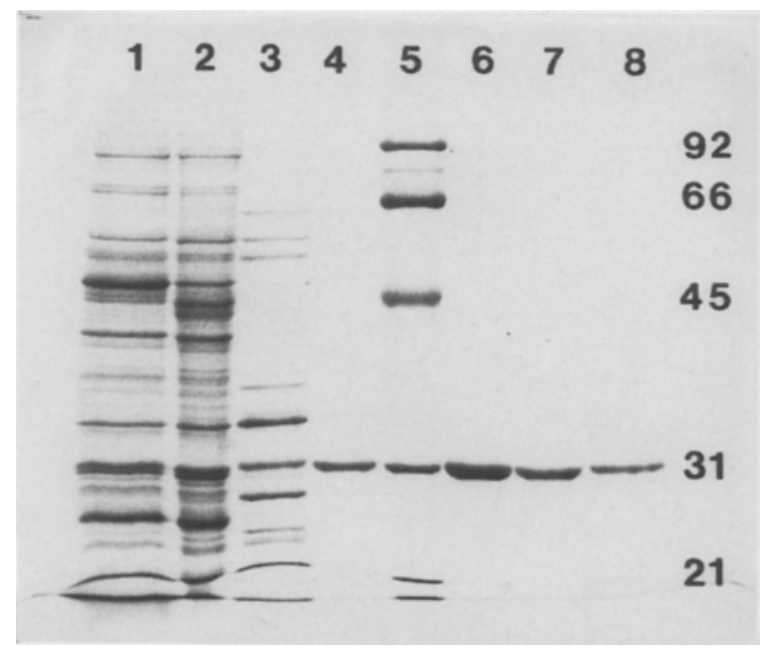

Figure 2. SDS-PAGE of nuclease produced by E. coli and $S$. marcescens. The samples applied to the gels had approx. the same activity (200 U). Purification of extracellular nuclease: Lane 1, clarified cell culture; lane 2, ammoniumsulfate precipitation; lane 3, DE-52 chromatography; lane 4, CM-Sepharose chromatography; lane 5, SDS-PAGE low molecular weight standards (Bio-Rad); lane 6, extracellular nuclease purified from S. marcescens strain W225; lane 7, purified extracellular nuclease from E. coli and S. marcescens; lane 8, purified periplasmic nuclease from E. coli. 
ase activity of $4 \mathrm{U} / \mathrm{ml}$ after $24 \mathrm{~h}$ of cultivation at the growth conditions chosen, the level of which is considered to be in accordance with reported activities (27).

The formation of extracellular nuclease activity by $\mathrm{E}$. coli cells with $\mathrm{p} 403-\mathrm{SD} 2$ resembles the production of nuclease by the $S$. marcescens strain used by NESTLE and ROBERTS (21). However, E. coli has the advantage above $S$. marcescens that it does not produce other extracellular proteins such as proteases, which can interfere with the purification of the enzyme. The results from the purification procedure of the extracellular nuclease are shown in Table 1 . The recovery was $62 \%$ of the activity measured in the medium. The purification was followed by SDSPAGE (Figure 2), and it is seen that a single band corresponding to a molecular weight close to 30,600 daltons was obtained. The periplasmic nuclease isolated by osmotic shock treatment was identical to the extracellular nuclease with regard to migration by SDS-PAGE. The nuclease isolated from $\mathrm{S}$. marcescens migrated similarly to the nuclease produced by E. coli, which indicates the ability of $\mathrm{E}$. coli to process the enzyme correctly.

The specific activity was determined to $4.0 \times 10^{4} \mathrm{U} / \mathrm{mg}$ on samples, where the protein concentration was estimated by amino acid analysis. The isoelectric point pl was determined to 6.85 . Nucleases from other $S$. marcescens strains previously examined had lower specific activity (21) and different isoelectric points $(9,29)$.

\subsection{Primary structure of nuclease}

The amino acid composition of nuclease expressed in E. coli was found to agree with the composition predicted from the recently report-

Table II. Amino acid composition of nuclease. No. of residues/molecule

\begin{tabular}{|c|c|c|c|c|}
\hline Amino Acid & E. coli & S. marcescens & From literature $^{b}$ & $\begin{array}{l}\text { Residues predicted } \\
\text { from the DNA } \\
\text { sequence }\end{array}$ \\
\hline Asp & $35.0^{\mathrm{a}}$ & $35.0^{2}$ & 35 & 35 \\
\hline Thr & $18.3^{\mathrm{c}}$ & 19.2 & 18 & 19 \\
\hline Ser & $18.2^{c}$ & 18.2 & 18 & 17 \\
\hline Glu & 16.8 & 17.6 & 18 & 16 \\
\hline Pro & 14.3 & 15.2 & 18 & 15 \\
\hline Gly & 16.2 & 17.7 & 15 & 16 \\
\hline Ala & 25.7 & 26.0 & 25 & 26 \\
\hline Cys & $3.3^{\mathrm{d}}$ & 2.2 & 3 & 4 \\
\hline Val & 14.5 & 14.1 & 13 & 14 \\
\hline Met & 1.9 & 2.1 & 3 & 2 \\
\hline lle & 11.3 & 11.6 & 10 & 12 \\
\hline Leu & 20.5 & 19.5 & 20 & 20 \\
\hline Tyr & 7.3 & 8.0 & 8 & 8 \\
\hline Phe & 5.8 & 6.1 & 8 & 6 \\
\hline His & 5.3 & 5.4 & 5 & 5 \\
\hline Lys & 16.6 & 15.0 & 15 & 15 \\
\hline Arg & 9.0 & 8.8 & 8 & 9 \\
\hline $\operatorname{Trp}$ & $6.4^{e}$ & $\mathrm{ND}^{r}$ & 6 & 6 \\
\hline
\end{tabular}

a From amino acid analysis as described in "Materials and Methods". Data on the basis of 35 Asp. Nuclease from S. marcescens strain W225 was only hydrolyzed for $24 \mathrm{~h}$.

'Filumonova et al. (10), data recalculated on the basis of 35 Asp except for Trp

' Extrapolated values

$\checkmark$ Determined as cysteic acid

- Determined spectrophotometrically (EDELHOCH (7))

'Not determined 
ed DNA sequence, BALL et al. (1) (Table II). The molar composition was calculated on the basis of 35 aspartic acids, obtained from the sequence as aspartic acid and aspargine (Table II). We found the same amino acid composition for nuclease purified from $\mathrm{S}$. marcescens strain W225. However, the amino acid composition deviates from previously reported results by Yonemura et al. (29) and Filimonova et al. (10). However, nearly the same composition could be obtained as recorded by Filimonova et al. (10), if their results were recalculated on the basis of 35 aspartic acids.

The amino acid sequence of the $35 \mathrm{~N}$-terminal residues was determined as well as a series of peptides generated by cleavage with cyanogen bromide and clostripain (Figure 3). About 80\% of the amino acid sequence predicted from the DNA sequence was confirmed; the $\mathrm{N}$-terminal amino acid was in our examinations determined to be an aspartic acid, which is different from the alanine suggested by BALL et al. (1).

The enzyme clostripain which was used for generating peptides for the sequencing, cleaves peptide bonds on the C-terminal side of Arg, but in three instances cleavage had also taken place after Lys (Lys-37, Lys-172, Lys-231). In addition, an unexpected peptide was obtained from cleavage between Leu-108 and Ser-109. N-terminal sequencing of the nuclease did not indicate any preexistance of this cleavage in the native enzyme.

\subsection{Assignment of disulfide bridges}

The negative result of the treatment of unreduced nuclease with Ellman's reagent under denaturing conditions showed that the four cysteins must exist as two disulfide bridges. Cleavage of native nuclease with clostripain followed by purification by HPLC generated a peptide Asp-1 to Arg-25, which contained two

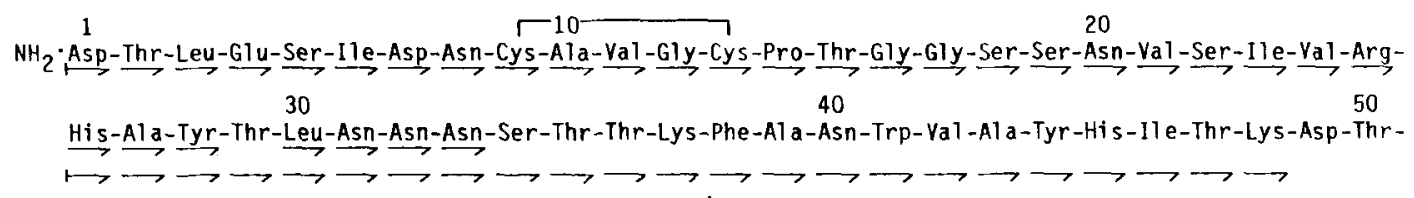

60

70

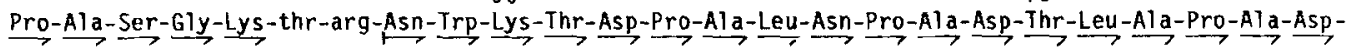
80

90

100

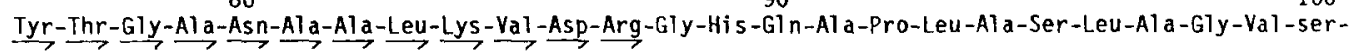

110

120

asp-trp-glu-ser-1eu-asn-tyr-leu-ser-asn-ile-thr-Pro-Gln-Lys-Ser-Asp-Leu-Asn-Gin-gly-ala-trp-ala-arg130

140

150

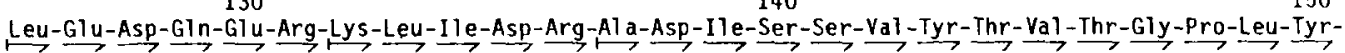

160

170

Glu-arg-asp-met-G1y-Lys-Leu-Pro-Gly-Thr-Gln-Lys-Ala-His-Thr-Ile-Pro-Ser-Ala-Tyr-Trp-Lys-Val-Ile-Phe-

180

190

200

Ile-Asn-Asn-Ser-Pro-Ala-Val-Asn-his-Tyr-Ala-Ala-phe-1eu-phe-asp-gln-asn-thr-pro-lys-gly-ala-asp-phe$\longrightarrow \longrightarrow \longrightarrow \longrightarrow \longrightarrow \longrightarrow \longrightarrow \longrightarrow \longrightarrow \longrightarrow+210 \quad 220$

cys-gln-phe-arg-val -thr-val-asp-glu-ile-glu-lys-arg-Thr-Gly-Leu-Ile-Ile-Trp-Ala-Gly-Leu-Pro-Asp-AspL

Val-Gln-Ala-Ser-Leu-Lys-Ser-Lys-Pro-Gly-Val-Leu-Pro-Glu-Leu-Met-Gly-cys-lys-asn-COOH

Figure 3. Amino acid sequence of nuclease. The sequence determination was performed on extracellular nuclease from E. coli. - $\longrightarrow$, the sequence determined by automated gas-phase Edman degradation. The remaining sequence $(20 \%)$ was predicted from the DNA-sequence (BALL et al. (1)); - disulfide bridges assigned; $\vdash$ start and direction of sequencing. 
Cys residues in position 9 and 13. Since the protein had not been reduced at this stage a disulfide bond must exist between Cys- 9 and Cys-13. The cleavage of unreduced nuclease with clostripain resulted also in the formation of two peptides Val-173 to Arg-204 and Ser-232 to Asn-245, which co-migrated on HPLC chromatography. This confirmed that the remaining two Cys residues in position 201 and 243 must be linked by a disulfide bridge. Examinations of disulfide bridges have previously been performed by FILIMONOVA et al. (10), and they found one -S-S-bridge and one SH-group.

\subsection{Molecular weight}

The molecular weight was determined to 30,600 daltons by HPLC gel filtration and SDSpolyacrylamide gel electrophoresis, but from the amino acid sequence it was calculated to 26,650 daltons. These values are all lower than other reported values $(9,29)$. Active nuclease could additionally be located by the blotting technique at a higher molecular weight although it was invisible on Coomassie Blue stained gels. When gels from SDS-PAGE with native enzyme were blotted onto nitrocellulose, and the nitrocellulose was placed on DNase test agar at room temperature, clearing zones visualized with $1 \mathrm{~N}$ $\mathrm{HCl}$ appeared at a position corresponding to a molecular weight close to $50-55,000$ daltons within $0.5 \mathrm{~h}$ and close to 30,000 daltons after some hours (results not shown). Nuclease from S. marcescens gave less pronounced but similar results. These results indicate that the enzyme can appear as a dimer. To confirm that the nuclease activities found did not arise from the E. coli itself, we repeated the blotting experiment with periplasmic extract from cultivated cells of E. coli MT 102 without plasmids and no similar activities were found.

\subsection{Effect of pH on enzyme activity and stability}

The activity of nuclease toward DNA was examined within the $\mathrm{pH}$ range 5 to 10 , and optimal activity was found at $\mathrm{pH} 8.5$ similar to results previously reported by NESTLE and ROBERTS (21). The stability of the enzyme in

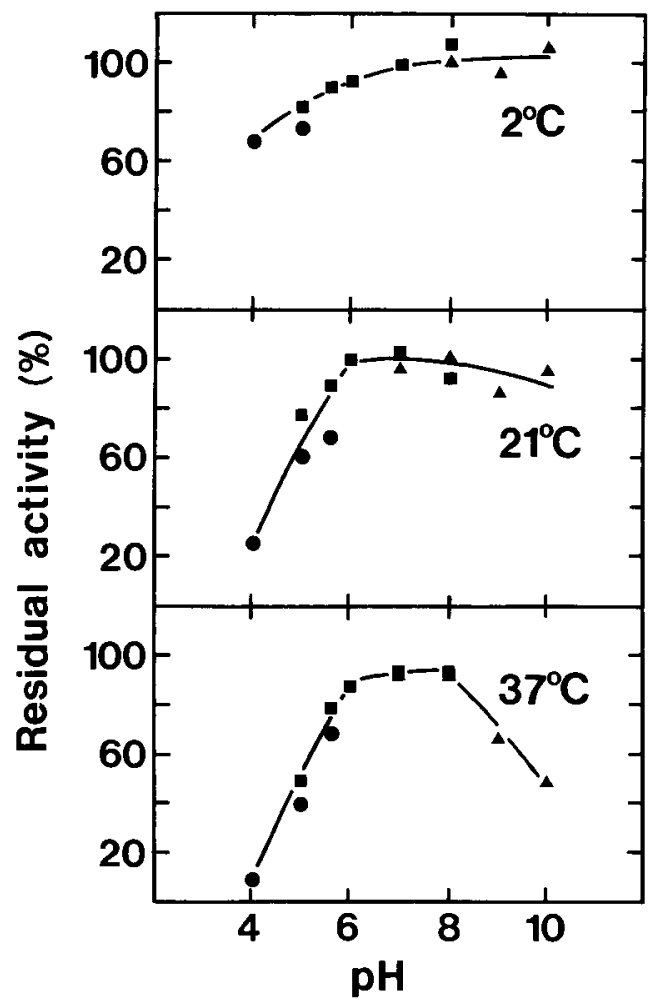

Figure 4. The effect of pH on the stability of nuclease. Extracellular nuclease purified from E. coli was incubated for $0.5 \mathrm{~h}$ at the temperature $2^{\circ} \mathrm{C}, 22^{\circ} \mathrm{C}$ and $37^{\circ} \mathrm{C}$ in the appropriate buffers. After the incubation the enzyme activity was measured; $\bullet$, sodium acetate buffer; $\boldsymbol{\omega}$, sodium phosphate buffer; $\boldsymbol{\Delta}$, Tris-HCl buffer.

buffers with $\mathrm{pH}$-values ranging from $\mathrm{pH} 4$ to $\mathrm{pH}$ 10 was examined at the temperatures $2{ }^{\circ} \mathrm{C}, 21^{\circ} \mathrm{C}$ and $37{ }^{\circ} \mathrm{C}$ (Figure 4). Within the $\mathrm{pH}$ range 6-8 the enzyme is stable for $1 / 2 \mathrm{~h}$ at all the temperatures. Additionally, we examined the stabilities at pH 5.6 to 8.5 at $2{ }^{\circ} \mathrm{C}$ over a period of $24 \mathrm{~h}$, and no loss of activity was measured.

\subsection{Effect of temperature on enzyme activity and stability}

The dependence of the enzyme activity on temperature was examined and an optimum for activity at $44^{\circ} \mathrm{C}$ was found. The stability of the enzyme at $\mathrm{pH} 8.0$ over a period at $24 \mathrm{~h}$ was measured at different temperatures (Figure 5). The enzyme maintained its activity at $22^{\circ} \mathrm{C}$ and $37^{\circ} \mathrm{C}$, but at $44^{\circ} \mathrm{C}$ and $60^{\circ} \mathrm{C}$ it lost most of the 
activity within $1 / 2 \mathrm{~h}$. Most of the activity could, however, be reestablished if the enzyme after the heat treatment was incubated at $4^{\circ} \mathrm{C}$ for $24 \mathrm{~h}$. If $\beta$-mercaptoethanol was added to a concentration of $2 \%$ before the cooling, no activity was regained. It was also found that $\beta$-mercaptoethanol had no inactivating effect on nuclease, which had not been heat treated. This reversible inactivation observed could therefore arise from breakage of disulfide bonds or dissociations of a possible dimeric conformation of the enzyme.

\subsection{The influence of $\mathrm{Mg}$ and urea on the enzyme activity}

Nuclease requires $\mathrm{Mg}^{2+}$ or $\mathrm{Mn}^{2+}$ for its activity. We found that the optimal enzyme activity was achieved with 5 to $10 \mathrm{mM} \mathrm{Mg}^{2+}$ ion as previously reported by NESTLE and ROBERTS (21). The influence of $4 \mathrm{M}$ and $8 \mathrm{M}$ urea on the activity was examined over a period of $60 \mathrm{~min}$. An increase in reaction rate was found with $4 \mathrm{M}$ urea relative to no addition of urea. $8 \mathrm{M}$ urea caused an inactivation after $5 \mathrm{~min}$ of reaction.

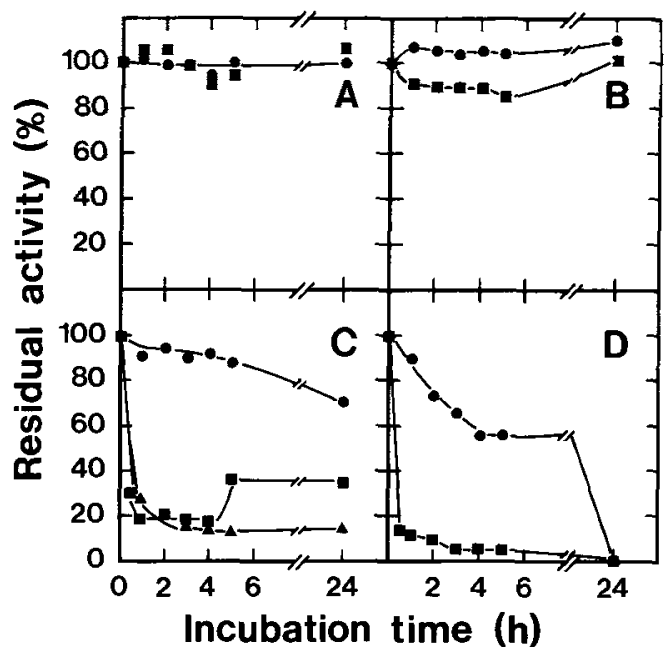

Figure 5. The effect of temperature on the stability of nuclease. Extracellular nuclease purified from E. coli was incubated in assay buffer at the temperatures $22^{\circ} \mathrm{C}$ (A), $37^{\circ} \mathrm{C}$ (B), $40^{\circ} \mathrm{C}$ (C) and $60^{\circ} \mathrm{C}$ (D): $\boldsymbol{\square}$, nuclease activity determined immediately after the heat treatment; $\bullet$, nuclease activity determined after an additional incubation at $4^{\circ} \mathrm{C}$ for $24 \mathrm{~h} ; \boldsymbol{\Delta}$, nuclease activity determined after an additional incubation at $4{ }^{\circ} \mathrm{C}$ for $24 \mathrm{~h}$ in the presence of $\beta$-mercaptoethanol (2\%).
Similar increase in activity with 4 and $7 \mathrm{~m}$ urea has been reported by Filimonova et al. (9).

\section{DISCUSSION}

The nuclease isolated from E. coli cell cultures appeared to be similar to at least two of the other nucleases previously isolated from other $\mathrm{S}$. marcescens strains $(9,21)$ with respect to physical and chemical properties despite several deviations. The amino acid composition and the sequence of 245 amino acids confirm the sequence predicted from the DNA sequence (1) and in addition the two disulphide bridges were assigned. The activity and stability studies presented here reveal that the enzyme has properties which can be used in a broad range of applications. According to NeSTLE and ROBERTS (21) the enzyme degrade DNA and RNA unspecifically. This property can be useful, e.g. for degrading DNA and RNA in cell homogenizates and thus improve the separation of intracellular proteins by centrifugation or microfiltration.

It appeared from the blotting studies that the enzyme might also have a dimeric configuration. Dimeric forms of a nuclease detected by SDS-PAGE have been reported (26). We did not find any free cystein residues, however, this does not exclude the possibility of trapped cysteins. Filimonova et al. (9) found one hidden cystein in their examinations. From the temperature stability studies it can be concluded that the enzyme can be reversibly inactivated. The enzyme did not renature when a reducing agent was present. Also the denaturing agent urea appeared to affect the active native structure. All these facts demonstrate that disulfides are involved in the active conformation. According to T.E. Creighton (5) the primary structure of a protein and the environment determine its conformational properties during the folding pathway. Changes in the environment can effect the formation of certain structures. This again effects the formation or omitting of formation of disulfides. In our previous study (BIEDERMANN et al. (2)) we found that the amount of extracellular enzyme produced during the cultivation of the E. coli cells was affected by the amount of dissolved oxygen in the culture. High aeration level, which has been used in this study, caused 


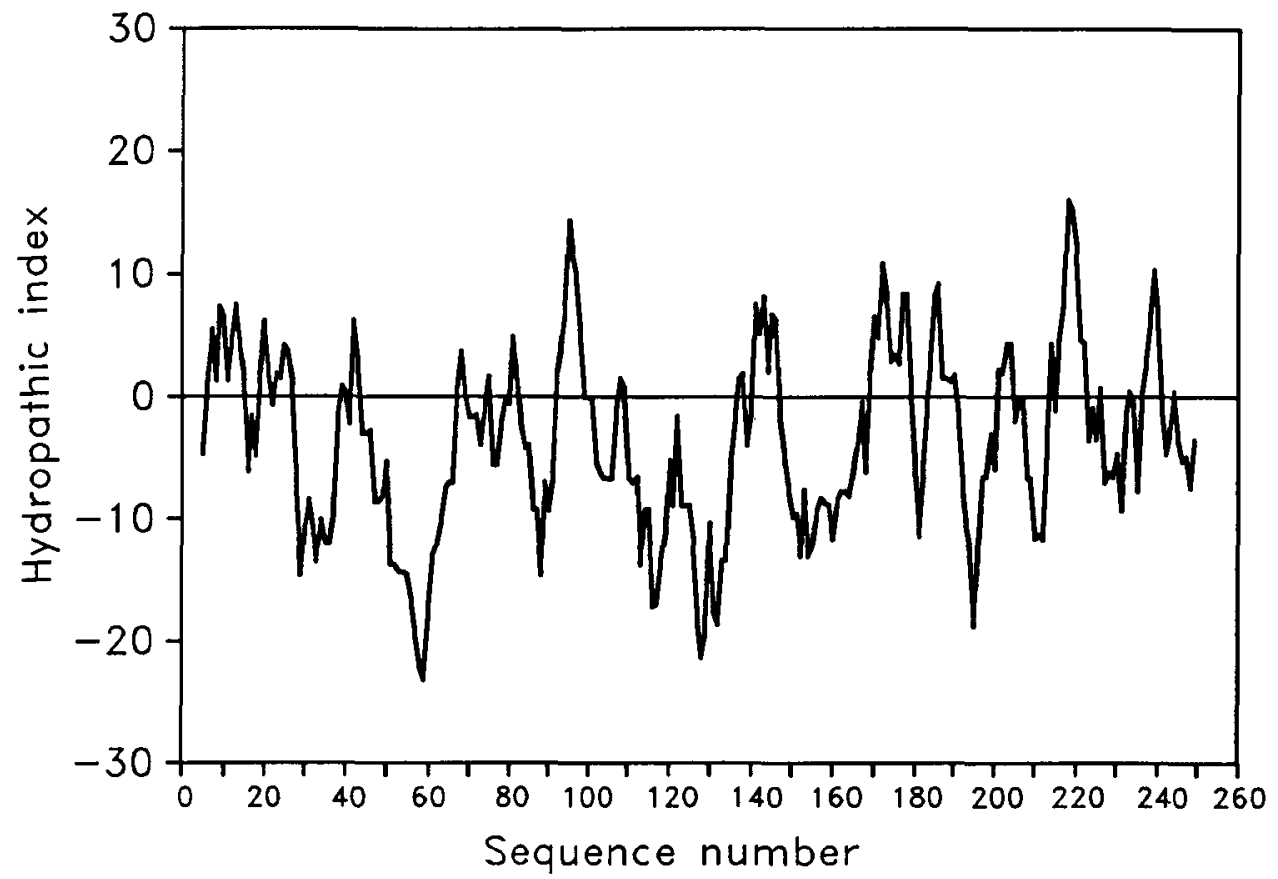

Figure 6. Hydropathy profile of the amino acid sequence of the nuclease. The profile was calculated from span setting of 9 amino acids according to the method of KYTE and DoOLITTLE (17).

the enzyme to be released to the medium. Low aeration level resulted in an accumulation of the enzyme in the periplasm. In this connection, the DNA sequence with the nuclease promoter upstream the nuclease encoding gene had great influence on the expression level and the transport across the outer membrane of the cell (2). It is likely that the high and low oxygen levels interfere with the folding of nuclease such that different conformations are favoured. If so, these structures can have different abilities to cross the outer cell wall.

The hydropathy profile was computed from the amino acid sequence according to KYTE and DOOLITTLE (17). It is seen from Figure 6 that the enzyme has mainly amino acid segments on the hydrophilic side of the midpoint. KYTE and DOOLITTLE (17) demonstrated a correlation between known structures of a variety of soluble globular proteins determined by crystallography and their hydropathy character. Segments found on the hydrophobic side of the midpoint were found in the interior of their native structures and hydrophilic segments were found on the exterior. If the hydropathy of nuclease follows the same system most segments must be at the exterior of the native structure. This can only be possible if the structure is "loose" or elongated. Interaction between the environment and the hydrophilic sequence is probably influencing the equilibrium between the random coil and the native structure during the folding procedure.

Apparently, the folding of nuclease takes place in the periplasm after translocation across the cytoplasmic membrane and cleavage of the signal peptide. Because the folding process may easily be affected of the cultivation conditions, this can be one of the reasons why the enzyme at some conditions is released to the medium and at some conditions not.

\section{ACKNOWLEDGEMENTS}

We thank Professor Søren Molin for his support and discussions, Dr. M.T. HANSEN for the E. coli strain and Dr. U. WINKLER for the S. marcescens strain. We also thank MERETE 
Pedersen, Bodil Corneliussen, lone SøRENSEN and PIA BREDDaM for excellent technical assistance. This work was supported by the Danish Technical Research Counsil and the Danish Natural Science Research Council.

\section{REFERENCES}

1. Ball. T.K., P.N. Saurugger \& M.J. Benedik: The extracellular nuclease gene of Serratia marcescens and its secretion from Escherichia coli. Gene 57, 183-192 (1987)

2. BiedermanN, K., H. Fiedler, B.S. LARSEN, E. RiISE, C. EMBORG \& P.K. JEPSEN: Comparative studies of constitutive and non-constitutive production of a nuclease from Escherichia coli. Appl. Environ. Microbiol. (In preparation) (1989)

3. BIEDERMANN, K.\& P.K. JePSEN; Release of periplasmic enzymes from Escherichia coli using tangential flow filtration. Biotechnol. Technique 3, 39-44 (1989)

4. BRADFORD, M.M: A rapid and sensitive method for the quantitation of microgram quantities of protein utilizing the principle of protein-dye binding. Anal. Biochem. 72, 248-254 (1976)

5. Creighton, T.E.: Disulfide bonds as probes of protein folding pathways. In; Methods in Enzymology (Hirs, C.H.W. \& Timasheff, S.N. eds.) Vol 131, pp. 83-106, Academic Press (1986)

6. EAVES, G.N. \& C.D. JEFFRIES: Isolation and properties of an exocellular nuclease of Serratia marcescens. J. Bacteriol. 85, 273-278 (1963)

7. EDELHOCH, H:: Spectroscopic determination of tryptophan and tyrosine in proteins. Biochemistry 6, 1948-1954 (1967)

8. EMBorg, C., P.K JEPSEN \& K BIEDERMANN: Two level factorial screening of new plasmid/strain combinations for production of recombinantDNA products. Biotechnol. Bioeng. in press (1989)

9. Filimonova, M.N., N.P. Balaban, F.R. Sharipova \& I.B. LECHCHINSKAYA: Isolation and physicochemical properties of homogenous nuclease from Serratia marcescens. Biokhimiya 45, 2096-2103 (1980)

10. Filimonova, M.N., L.A. Baratova, N.D Vospel nikova, A.O. Zheltova \& I.B. LeshChIN. SKAYA: Some properties of endonuclease from Serratia marcescens. Biokhimiya 46, 1660-1666 (1981)

11. Givskov, M., L. Olsen \& S. Molin: Cloning and expression in Escherichia coli of the gene for extracellular phospholipase A 1 from Serratia liquefaciens. J. Bacteriol. 170, 5855-5862 (1988)
12. Hines, D.A., P.N. Saurugger, G.H. Ihler \& M.J. BENEDIK: Genetic analysis of extracellular proteins of Serratia marcescens. J. Bacteriol. 170, 4141-4146 (1988)

13. HIRS, C.H.W.: Performic acid oxidation. In: Methods in Enzymology (Hirs, C.H.W., ed.) Vol. 11 pp 197-199, Academic Press, New York and London (1967)

14. Jepsen, P.K., E. RiIse, K. Biedermann, P.C.R. KrisTENSEN \& C. EMBORG: Two-level factorial screening for influence of temperature, $\mathrm{pH}$ and aeration on production of Serratia marcescens nuclease. Appl. Environ. Microbiol. 53, 2593-2596 (1987)

15. Kato, C, T. Kobayashi, T. Kudo, T. Furusato, Y. Murakami, T. Tanaka, H. Baba, T. OISHI, E. OTHSUKa, M. IKEHaRA, T. Yanagida, H. Kato, $\mathbf{S}$. MORIYAMA \& K. HORIKOSHI; Construction of an excretion vector and extracellular production of human growth hormone from Escherichia coli. Gene 54, 197-202 (1987)

16. KYHSE-ANDERSEN, J.: Electroblotting of multiple gels: a simple apparatus without buffer tank for rapid transfer of proteins from polyacrylamide to nitrocellulose. J. Biochem. Biophys. Methods 10, 203-209 (1984)

17. KYTE, J. \& R.F. DoolitTle: A simple method for displaying the hydropathic character of a protein. J. Mol. Biol. 157, 105-132 (1982)

18. LAEMML, U.K: Cleavage of structural proteins during the assembly of the head of bacteriophages T4. Nature 227, 680-685 (1970)

19. Moks, T., L. Abrahmsén, B. Öterlöf, S. JosphSON, M. Östling, S.-O. Enfors, I. Persson, B. NILSSON \& M. UHLĖN: Large-scale affinity purification of human insulin growth factor I from culture medium of E. coli. Bio/Technology 5, 379-382 (1987)

20. Molin, S., M. Givskov \& E. Risse: Production of bacterial hydrolases by genetic engineering. International Patent No. WO 86/06743 A1 (1986)

21. NestLE, M. \& W.K. Roberts: An extracellular nuclease from Serratia marcescens. 1. Purification and some properties of the enzyme. J. Biol. Chem 244, 5213-5218 (1969a)

22. NESTIE, M. \& W.K. ROBERTS: An extracellular nuclease from Serratia marcescens. 11. Specificity of the enzyme. J. Biol. Chem. 244, 5219-5225 (1969b)

23. NEU, H.C. \& L.A. HePPEL: The release of enzymes from Escherichia coli by osmotic shock and during the formation of spheroplasts. J. Biol. Chem. 240, 3685-3692 (1965)

24. NiCaud, J.M., N. MaCKMan \& I.B. Holland: Current status of secretion of foreign proteins by microorganisms. J. Biotechnol, 3, 255-270 (1986) 
25. Riddles, P.W., R.L. Blakeley \& B. Zerner: Reassessment of Ellman's reagent. In: Methods in Enzymology (Hirs, C.H.W. and Timasheff, S.N., eds.) Vol. 91, pp 49-60, Academic Press (1983)

26. ROSENTHAL, A.L. \& S.A. LACKS: Nuclease detection in SDS-polyacrylamide gel electrophoresis. Anal. Biochem. 80, 76-90 (1977)

27. WINKLER, U. \& K. TIMMIS: Pleotropic mutations in Serratia marcescens which increase the synthesis of certain exocellular proteins and the rate of spontaneous prophage induction. Molec. Gen. Genet. 124, 197-206 (1973)

28. Yanagida, N., T. Uozumi \& T. Beppu: Specific excretion of Serratia marcescens protease through the outer membrane of Escherichia coli. J. Bacteriol. 166, 937-944 (1986)

29. Yonemura, K., K. Matsumoto \& H. Maeda: Isolation and characterization of nucleases from a clinical isolate of Serratia marcescens kums 3958. J. Biochem. 93, 1287-1295 (1983)

Accepted by H. KLENOW 